\title{
Gore under fire in controversy over South Africa AIDS drug law
}

[WASHINGTON] US Vice-President Al Gore's campaign for the presidency has became caught up in an escalating controversy over his opposition to a South African law aimed at providing low-cost AIDS drugs.

Gore, who officially launched his campaign last week, has actively opposed South Africa's Medicines and Related Substances Control Amendment Act. This seeks to bypass existing patents to allow the manufacture or import of expensive AIDS drugs at significantly lower costs than those currently charged by the pharmaceutical industry.

The law was approved by the country's parliament in 1997. But it has not been implemented because 41 pharmaceutical companies, led by the Pharmaceutical Manufacturers' Association of South Africa (PMASA), have challenged it in the High Court in Pretoria.

The law would allow compulsory licensing and parallel importation of medicines by South Africa. This means either that manufacturers inside the country could bypass patents and make the drugs more cheaply, paying only royalties to the patent holder; or that South Africa could import the drugs from third countries in which they are already less expensive.

The AIDS epidemic has exploded in South Africa, where recent surveys in pregnancy clinics indicate that 22 per cent of sexually active adults are infected (the figure was 14 per cent in 1997). But the latest AIDS therapy costs US $\$ 800$ a month in South Africa, where the average annual income is $\$ 2,600$.

"We have a Third World country that has this horrifying pandemic, and we can't afford the drugs," says Robert Shell, a

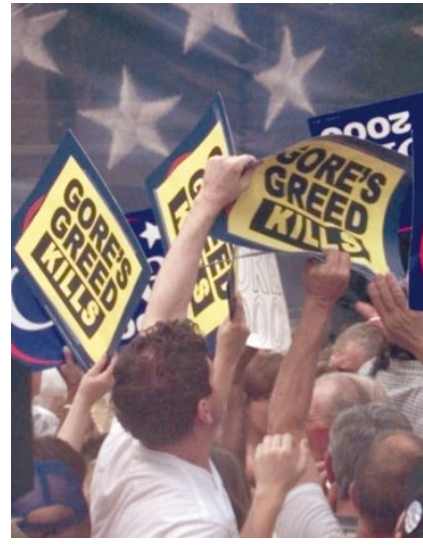

demographer at Rhodes University in Grahamstown, South Africa, who tracks the epidemic. "It is a question of life and death."

But the South African law has riled the US government and the pharmaceutical industry. They claim that it is striking at the heart of the patent protection necessary for drug development. Led by Gore and the US trade representative, the US has pressed South African officials to rescind or rewrite the law.

A spokesman for Gore says he and Thabo Mbeki, the South African president, "are committed to working together to chart a course that will meet the medical needs of those infected with HIV or AIDS, without cutting off the commercial incentives that fuel medical research".

Gore and Mbeki co-chair the US-South Africa Binational Commission, an economic diplomacy group. The spokesman adds that Gore "has a very strong record of efforts to fight AIDS in South Africa and his stands have been consistent with that".

But the perception that Gore is leading an

\section{G8 leaders seek study on effects of biotech}

[LONDON] A proposal from the French president Jacques Chirac to set up an international council of scientists to validate new foods was rejected at last weekend's summit of leaders of the G8 industrialized countries in Cologne.

But the participants pledged a "sciencebased, rules-based" approach to addressing the consequences of biotechnology. The meeting also agreed to commission a study of the implications of biotechnology from the Organization for Economic Cooperation and Development. The findings will be considered at the next summit.

The Chirac proposal fell foul of the US delegation, which described it as protectionist. But environmental issues were prominent in the meeting's final communiqué.

The meeting pledged to clarify the relationship between the rules of the World Trade Organization (WTO) and United Nations environment conventions. This is a reference to the impasse between the Trade Related Agreement on Intellectual Property Rights of the WTO, and the UN biodiversity convention over the sharing of benefits from patents on indigenous plants. The meeting also pledged "early entry into force" of the Kyoto Protocol on climate change.

Education was another major theme. Delegates promised to promote more teacher and student exchanges between the G8 and other countries.
Ehsan Masood
Campaign chaos: Gore's bid for the presidency got off to a bad start last week. Protesters disrupted his candidacy announcement, waving placards condemning his opposition to a South African law that could let AIDS drugs be sold more cheaply. effort to deny cheap drugs to a country in a desperate plight is making its mark in the United States. International health and AIDS activists dogged Gore on the campaign trail last week, chanting "Gore's greed kills".

"History will judge people harshly as to how they acted in this crisis. And it's going to be a harsh judgement on Gore," says James Love, director of the Consumer Project on Technology, an advocacy organization affiliated to Ralph Nader.

Love and Nader wrote to Gore in April accusing him of using "an astonishing array of bullying tactics" to stop South Africa expanding access to AIDS drugs.

Even members of the Presidential Advisory Council on HIV/AIDS are challenging Gore. "He is wrong," said council member Debbie Runions, a former Gore campaign volunteer, speculating whether "he's in the pockets of the pharmaceutical companies".

Critics allege that the vice-president, who has typically embraced liberal causes such as the fight against AIDS, is being swayed by ties to the drug industry. For instance, a key lobbyist for the Pharmaceutical Research and Manufacturers of America (Pharma), Tony Podesta, is the brother of the president's chief of staff, John Podesta, and is also a Gore adviser and friend.

According to the Center for Responsive Politics, a Washington-based public-interest group, Gore's political action committee received $\$ 56,000$ from individuals connected to pharmaceutical companies in 1998.

The vice-president's office denies that he has been influenced by drug makers. Officials point out that when Pharma asked the government last year to threaten South Africa with trade sanctions, it was rebuffed.

The country was merely placed on a 'watch list' of countries suspected of violating US intellectual property rights - a category that does not trigger sanctions. But two months later the White House announced 
that it was denying preferential tariff treatment for four South African imports.

South Africa's new health minister, Manto Tshabalala-Msimang, told Nature that the law is meant to address the "legacy of apartheid". "We don't want to interfere with the patent rights, but we want to get drugs of quality at a price we can afford," she says.

"Why would you want to buy the drug at SAR80 (US\$13) when if you import it you would get it at SAR30?" she asks. "In situations of emergency, what do you do? This is the question I would pose to PMASA."

Nonetheless, she says, she is making it "very high on my priority list" to meet the drug makers. She says the government is willing to negotiate the implementation of the law "in such a way that it meets the needs of the pharmaceutical industry".

That will take some doing, according to the drug companies. "This is a major issue," says Jeff Trewhitta, spokesman for Pharma. "The cost of research is very high. Patent protection is the lifeblood of the industry."

Mirryena Deeb, chief executive officer of PMASA, says the law is so broad that it "undermines the patent law system" and allows the health minister to "just take away the patent right".

An official at the office of the US Trade Representative (USTR), which has aggressively lobbied South Africa to reverse the law, calls it "offensive". "They've decided that the way to solve the [AIDS] problem is to deny intellectual property rights."

The USTR, Gore and the drug groups argue that the law breaches an important World Trade Organization (WTO) agreement on trade-related aspects of intellectual property protection, the 'TRIPS' agreement.

But Gore's critics read the agreement as allowing precisely the kind of action South Africa has taken. The agreement says compulsory licensing is permitted in cases of "national emergency or extreme urgency".

Some observers say that the TRIPS language is sufficiently ambiguous for there to be honest disagreement on whether South Africa is in breach of it. What angers some, says one international health official, is that "commercial interests are leading [the US government to use] pressure tactics", rather than using WTO dispute mechanisms.

According to a State Department report presented to Congress in February, Gore, the USTR, the Department of Commerce and the State Department have mounted an "assiduous, concerted campaign" to overturn the South African law.

Some argue that the issue goes beyond patent rights. Tom Coates, director of the AIDS Research Institute at the University of California, San Francisco, warns of the danger of drug resistant viral strains developing if the drugs are not imported in the right combinations and quantities, and administered with proper oversight. MeredithWadman

\section{Chlorine industry says EPA rules ignore good science}

[WASHINGTON] The US Environmental Protection Agency (EPA) is being taken to court by the Chlorine Chemistry Council, a Washington-based group representing chlorine manufacturers and users. The case could determine not only how the agency assesses cancer risks, but how it weighs scientific evidence in crafting regulations.

A federal court will hear arguments next year charging that the EPA failed to use the best available scientific information when it set goals for the maximum amount of chloroform allowed in drinking water.

Chloroform, the most common chemical by-product of water disinfection, causes cancer in laboratory animals when administered at very high doses. The scientific issue concerns whether there is a dose below which chloroform is safe.

EPA guidelines for assessing cancer risk extrapolate linearly the harmful effects seen at high doses, so that any dose is considered harmful. But a non-zero safe 'threshold' could theoretically be set if enough were known about a chemical's mode of action.

The controversy over chloroform began in March 1998, when the agency released new data on disinfection by-products, and announced that it was considering changing the goal for chloroform contamination in drinking water from zero to 300 milligrams per litre - the first acknowledgement of a threshold dose for a regulated carcinogen.

But in last December's final ruling, the agency retreated from this position, and set the goal at zero. The Chlorine Chemistry Council, water utilities and other groups claimed the agency had buckled to pressure from environmentalists, and filed suit. Complying with the new regulations is estimated to cost industry $\$ 1$ billion a year.

The International Society of Regulatory Toxicology and Pharmacology (ISRTP), which, along with the chlorine council, sponsored a meeting in Washington on the EPA's chloroform policy, said in a statement that there was "no justification for the EPA management's decision to ignore the advice of its own scientists".

Agency scientists conducted an extensive review of chloroform in the five years leading up to the March announcement, considering more than 30 toxicological studies and cosponsoring a 1997 review by the International Life Sciences Institute. Based on that analysis, the EPA concluded that "a nonlinear [threshold] approach is more appropriate for extrapolating low-dose cancer risk than the low-dose linear approach".

Agency scientists involved in the work say they were frustrated, therefore, when the

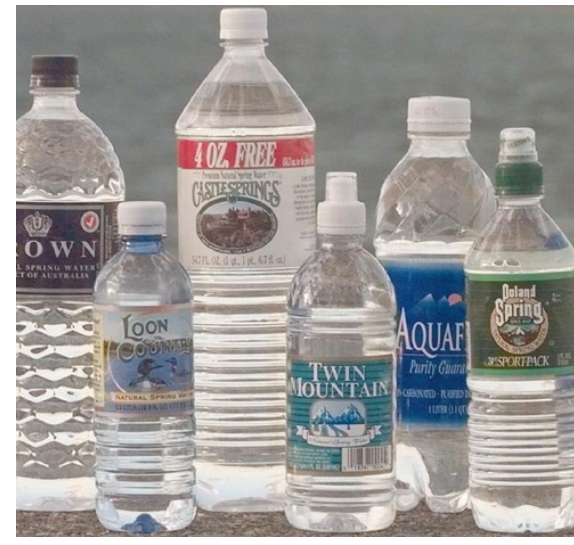

Bottling out: as sales of bottled water rise, court case focuses attention on the safety of tap water.

EPA reverted to the linear approach in its final ruling.

Erik Olson of the Natural Resources Defense Council (NRDC), a Washingtonbased environmental group that opposes a non-zero goal, says the episode reveals "deep divisions" within the agency.

Language in the December ruling bears this out. Calling the zero goal an "interim risk-management decision," the agency said that even though the "underlying science for using a nonlinear extrapolation approach... is well founded," further discussion was needed, as the new approach would represent a "significant and precedential, albeit sound, application of new science to the policy and risk-management decision-making process".

The Chlorine Chemistry Council hopes to exploit that candidness, arguing that the agency has not used the best available peerreviewed science, as laws governing drinking water safety require. Oral arguments will be heard in a federal circuit court in Washington, which recently overturned EPA regulations on air pollution, partly on the basis of inadequate justification.

Olson believes the EPA made the right choice in December, and points out that not all scientists agree that the mode of action for chloroform carcinogenicity is well enough established to end the zero-tolerance policy.

But many toxicologists see the EPA's action as a stalling tactic. "When we have data, the simple use of a default represents a failure," said Jay Goodman, president of the Society of Toxicology.

EPA guidelines for assessing cancer risk have been under review for nine years, and have been further delayed by an additional review to consider children's health. The agency's science advisory board last month urged the EPA to publish the guidelines "as soon as judiciously possible”. Tony Reichhardt 